академія, за зразком якої вони виникали. Ці навчальні заклади підпорядковувалися церковному керівництву єпархії, на території якої розташовувались, та були доступні усім станам.

\title{
Література
}

1. Полное собрание законов Российской империи с 1649 года : в 45 т. T. VI : № 3718, (17201722 гг.) - СПб. : Тип. ІІ отделения собственной Его Император. Величества канцелярии, 1830. 815 с. 2. Україна. Хронологія розвитку : в 6 т. Т.4. / уклад. : О. О. Григор’єва, О. І. Смельяненко, М. І. Мацола [та ін.] ; редкол.: П. П. Толочко, Г. Ю. Івакін, Л. Л. Залізняк [та ін.]. - К. : КРІОН, $2009 . \quad-864$ с. 3. Українська культура в європейському контексті / Ю. П. Богуцький, В. П. Андрущенко, Ж. О. Безвершук, Л. М. Новохатько ; за ред. Ю. П. Богуцького. - К. : Знання, 2007. - 679 с. 4. Харлампович К. В. Малороссийское влияние на великорусскую церковную жизнь : Т. 1. / К. В. Харлампович. - Казань : Изд-во книжн. магазина М. Г. Голубева, 1914. - 878 с. 5. Хижняк 3. І. Історія Києво-Могилянської академії / 3. І. Хижняк, В. К. Маньківський. - 2-ге вид., допов. і перероб. - К. : Києво-Могилян. акад., 2008. - 203 с. б. Шевченко О. М. Україна і Росія у світлі релігійно-культурних взаємин другої половини XVII-XVIII ст. / О. М. Шевченко // Укр. іст. журн. - К. : Наук. думка, 1996. - № 1. - С. 82-90.

УДК $37.035 .3(045)(477)$

Л. А. Черкашина, асистент, Державний вищий навчальний заклад «Донбаський державний педагогічний університет»

\section{РЕТРОСПЕКТИВНИЙ ОГЛЯД ПЕРІОДИЧНОГО ВИДАННЯ «ГУМАНІЗАЦІЯ НАВЧАЛЬНО-ВИХОВНОГО ПРОЦЕСУ» (1996-2000 рр.) 3 ПИТАНЬ ТРУДОВОГО ТА ЕКОЛОГІЧНОГО ВИХОВАННЯ УЧНІВ}

Черкашина Л. Ретроспективний огляд періодичного видання «Гуманізація навчально-виховного процесу» (1996-2000рр.) з питань трудового та екологічного виховання учнів.

Статтю присвячено висвітленню питань трудового й екологічного виховання учнів навчальних закладів на сторінках фахового періодичного видання «Гуманізація навчально-виховного процесу» 31996 р. по 2000 р. Автором здійснено аналіз праці педагогів 3 проблем усебічного i гармонійного розвитку особистості, наголошено на важливості екологічного виховання, зосереджено увагу на трудовому вихованні учнів як необхідному чиннику соціалізації особистості.

Ключові слова: збірник, наукова періодика, трудове, екологічне виховання, учні навчальних закладів, особистість.

Черкашина Л. А. Ретроспективный обзор периодического издания «Гуманизация учебновоспитательного процесса» (1996-2000 гг.) по вопросам трудового и экологического воспитания учащихся.

Статья освещает вопросы трудового и экологического воспитания учащихся учебных заведений на страницах сборника научных трудов «Гуманизация учебно-воспитательного процесса» с 1996 г. по 2000 г. Автором проанализированы труды педагогов по проблемам всестороннего и гармонического развития личности, подчеркнута важность экологического воспитания, особое внимание сосредоточено на трудовом воспитании учащихся как необходимом факторе социализации личности.

Ключевые слова: сборник, научная периодика, трудовое, экологическое воспитание, учащиеся учебных заведений, личность.

Cherkashina L. A. Retrospective review of the periodic publication the «Humanization of trainingeducate process» (1996-2000 years) on the issues of labor and ecological education with schoolchildren.

The article covers the issues of labour and ecological education of students of educational institutions on the pages of the collection of scientific works the «Humanization of training-educate process» from 1996 to 2000. The author analyzed the works of teachers on the problems of the full and harmonious development of the personality, emphasizes the importance of environmental education, attention is 
focused on the labor education of students as a necessary factor of existence of the individual in society.

Key words: collection of scientific periodicals, labour, environmental education, students of educational institutions, person.

Загальновідомо, що освіта синтезує в собі знання 3 історії, філософії, соціології, політології, психології, фізіології та інших дисциплін. Її розвиток безпосередньо залежить від суспільного, економічного і політичного життя країни, а також є одним із найважливіших соціальних інститутів, що переживає періодичні оновлення, проходить процес еволюції і перманентного реформування.

Зміни в соціальному устрої української держави, розвиток науки і техніки, поява нової ідеології є вагомими чинниками для усвідомлення значення праці у вихованні дітей до дорослого життя, отримання ними практичних вмінь та навичок. На наш погляд, сім'я, громадські установи, освітні та позашкільні заклади приділяють недостатню увагу трудовому вихованню юних членів суспільства. Ці соціальні інститути відіграють важливу роль у становленні та розвитку особистості, у прищепленні дітям любові до праці, набутті необхідних у дорослому житті трудових умінь і навичок.

Зазначимо, що трудове виховання - змістовне і широке поняття, яке належить до системи загальнолюдських, національних, громадянських i патріотичних цінностей. Трудове виховання здійснюється всіма ланками освіти, особливу увагу йому приділено на заняттях з трудового навчання (технології), у процесі вивченні предметів природничого циклу, під час відвідування гуртків юних натуралістів у позакласній і позашкільній роботі.

Зауважимо, що друкованим засобам масової інформації, їхньої різнопланової змістової насиченості присвячено наукові праці багатьох провідних вітчизняних дослідників, а також молодих науковців. Проблеми шкільної дидактики на західноукраїнських землях(1918-1939рр.), питання історії, теорії і практики науково-просвітницької преси України XIX-першої третини XX ст. висвітлено у дослідженнях Т. Завгородньої, О. Коновець [4; 6]. Питанню виховного національного ідеалу у школах на західноукраїнських землях 20-30-х рр. ХХ ст. приділено увагу у працях М. Кухти [7]. Вирішення актуальних проблем міських і сільських шкіл в історичному вимірі часу на шпальтах національної періодики знаходимо у науковому доробку Г. Щуки [12].

Отже, історіографія джерельної бази фахової періодики щодо вивчення питання трудового й екологічного виховання не була окремим предметом окремого дослідження. Тому періодику можна і необхідно використовувати як джерело виховного впливу на особистість і громадську думку як потужний інструмент у формуванні національної свідомості. Вона є дієвим засобом морального, естетичного, екологічного, трудового, патріотичного виховання.

Мета статmi - здійснити об’єктивний аналіз фахового періодичного видання «Гуманізація навчально-виховного процесу» з 1996 р. по 2000 р., у якому автори статей підіймають питання трудового і екологічного виховання учнів у навчальних закладах.

Збірник наукових праць «Гуманізація навчально-виховного процесу» започатковано у 1996 р. кафедрою педагогіки Слов'янського державного педагогічного інституту (нині Донбаського державного педагогічного університету). Уже з другого випуску Постановою президії ВАК України № 2/7 від 11 вересня 1997 р. наукове видання затверджено фаховим 3 педагогічних наук, у якому можуть публікуватися результати наукових робіт на здобуття наукового степеня доктора і кандидата наук. Періодичне видання виходить регулярно вже 16 років, налічує 60 випусків, 11 спецвипусків, де оприлюднено матеріали конференцій різного рівня.

У першому номері періодичного видання доцент кафедри педагогіки А. Глущенко вказував на виховний вплив праці, що викликана необхідністю, і розкрив зміст поняття «необхідність» у трудовому вихованні. Отже, необхідність - це обставини чи причини у конкретних життєвих умовах, що спонукають дітей до праці, на підставі яких виникає трудовий мотив (привід). Коли такі зв'язки реалізуються, то виникає відповідальне ставлення до праці. Дитина розуміє свою працю як необхідність спільної праці. Реалізація 
зв'язків сприяє накопиченню досвіду, зумовлює виникнення почуття відповідальності, формується вимогливість до себе. Праця стає необхідним обов'язком і «перетворюється на власну потребу дитини» [1, с. 17]. Також А. Глущенко звертається на надбань А. Макаренко, який наголошував на необхідності у книжці «Лекції про виховання дітей. Виховання в праці», зазначаючи, що необхідність відіграє важливу роль. За словами педагога з соціального виховання, дитина розуміє працю, коли розуміє у ній користь i знаходить у ній радість, тільки тоді праця стає творчою, слугує розвитку талантів [1, с. 17]. автор статті поділяє думку В. Сухомлинського, який постійно звертався до надбань народної мудрості, говорячи при цьому, що «вища педагогічна мудрість трудового виховання полягає в тому, щоб утвердити в дитячому серці народне ставлення до праці» [1, c. 17]. Одночасно із виконанням дитиною трудових операцій приходить почуття задоволеності, успіху, разом із тим виникає особиста потреба у праці. Отже, Г. Глущенко наводить дані про проведені спостереження серед учнів молодших класів. Виявляється, що у дітей, які виконують трудові обов'язки в домашньому господарстві, виникає почуття впевненості, турботливості, ініціативності, значно зростає рівень вихованості, трудової підготовки.

У 1996 році вийшла стаття В. Сипченка, С. Омельченко «Виховання моральноціннісного ставлення до праці в умовах ринкових відносин», в якій вони звернули увагу на те, що ринкові відносини вимагають від випускників навчальних закладів професіоналізму, мобільності і переорієнтації. Трудове виховання спрямовано на формування моральноціннісного ставлення до праці, тобто праця є складником системи найвищих людських цінностей. У старшокласників особиста зацікавленість у праці слугує стимулом для розвитку ділових якостей, вимогливості, енергійності. Високий професіоналізм $\epsilon$ фундаментом для подальшого успіху і кар'єрного росту [10].

У статті С. Омельченко висловлено думку про розроблення інноваційної моделі трудового виховання підлітків в умовах ринкових відносин. Викладено концептуальні положення щодо самостійної трудової діяльності учнів: 1) мета, зміст, форми і методи трудового виховання повинні бути спрямовані на досягнення соціального досвіду; 2) моральними цінностями є працелюбність, чесність, відповідальність, професіоналізм, витриманість тощо [9].

М. Євтухом, К. Потапенко презентовано педагогічні надбання вітчизняного письменника - М. Гоголя. У своїх працях М. Гоголем викладено план гармонійного розвитку дитини, у якому провідну роль відведено розумовому вихованню, що, в свою чергу, $\epsilon$ підгрунтям для вироблення моральних переконань. У моральному вихованні особистості провідну роль відведено праці, яка звеличує людину, а неробство i дармоїдство, на думку українського письменника - людські вороги. М. Гоголь радив привчати дітей до праці ще змалку. Зосереджував увагу на тому, що школа повинна мати тісні зв'язки з практикою. Під працею розумілася суспільна корисна праця, спрямована на благополуччя інших і $є$ джерелом душевного спокою і активізують почуття задоволення [3, с. $10-11]$.

Ознайомленню широкого кола педагогів зі здобутками зарубіжного досвіду з питань трудового виховання слугує стаття В. Домнич. Автор, спираючись на іспанський народний фольклор, описує виховний вплив праці. Можна помітити, що всі народи спільні в одному, що без трудового виховання неможливий всебічний і гармонійний розвиток особистості. Іспанські народні прислів’я співзвучні з українськими: «Не відкладай на завтра те, що можна зробити нині» (укр.) - «Сказано-зроблено» (ісп.). Особливу роль відіграє усна народна творчість, ремесла, трудові традиції, ігри. Через них у дитини розвиваються високоморальні чесноти: чесність, працьовитість, добропорядність, дисциплінованість. Отже, праця є дієвим засобом у вихованні, без неї неможливий гармонійний розвиток особистості.

Продовженням попередньої теми $є$ стаття Г. Чупилко «Принцип гуманізації у трудовому вихованні підростаючого покоління». Автор звертається до скарбниці народної 
мудрості, у якій провідне місце займає трудове виховання. Праця у народі возвеличувалася і вважалася невід'ємним джерелом існування: «Без труда нема плода», «Без роботи ані хліба, ані хати» [11, с. 213]. Дитина вважалася вихованою, якщо вміла працювати змалку. Тому дітей батьки залучали до виконання посильних трудових обов'язків «Люби труд змалку, слухатимеш весь вік похвалу» [11, с. 213]. Посильна праця слугувала не тільки вихованню працелюбності, трудового досвіду, а й сприяла підготовки до дорослого життя, виконанню суспільних обов'язків: «Будеш трудитися - будеш кормитися», «Хто добре працює, тому і щастить» [11, с. 213].

Г. Чупилко наводить міркування педагогів XIX ст. щодо устрою земських шкіл. Учителем П. Лисициним викладено думку створення при сільських школах плодових садів і городів. Заняття садівництвом і городництвом корисна дітям і навчальному закладу не тільки тому що учні набувати трудових умінь і навичок, а школи забезпечувалися продуктами харчування, мали додаткові кошти з продажу овочів, насіння, плодів і дерев. Дівчата Юзівською братської школи займалися рукоділлям, працювали у саду [11, с. 214].

Автором статті проаналізовано організацію навчання і виховання у народних школах XIX ст., де вчителі намагалися організовувати працю таким чином, щоб учні були підготовлені до життя, були фізично розвинені. У цих закладах приділялося увагу змаганням, велику роль відігравав приклад учителів, шанування праці інших людей, залучення до самообслуговування. Нині більшість шкільних земельних ділянок перебувають у занедбаному стані, відсутня суспільна праця, що призводить до безвідповідальності і байдужості. Педагог, поділяючи думки К. Ушинського, впевнена, що готувати дітей треба для праці за нахилами і інтересами. За визначенням Г. Сковороди, тільки коли праця стає «головним обов'язком і моральною потребою, вона приносить щастя людині» [11, с. 216].

У восьмому номері збірника надруковано статтю О. Ковальової про соціальнопедагогічну діяльність С. Шацького. Будучи небайдужим до проблем дітей, С. Шацький організовує разом із однодумцями виховний заклад «Сетлемент». Суспільне життя в установі базувалося на ідеях товариськості, співпраці, взаємопорозуміння, створення невимушеної, доброзичливої атмосфери, на демократичних і гуманістичних принципах. Педагоги разом із вихованцями працювали на городі, готували їжу на кухні, майстрували, займалися благоустроєм території, грали у рухливі ігри тощо [5, с. 223].

Центральне місце у практиці роботі 3 дітьми педагогом відведено праці дітей. С. Шацький уважав іiї основою дитячого життя й основним методом виховної роботи [5, c. 225]. Педагог був переконаний у тому, що навчання дітей ремеслу призводить до механічних виконань операцій, тому «він прагнув прищепити дітям інтерес до самого трудового процесу, викликати у них радість трудового напруження» у повсякденній побутовій праці [5, с. 226].

Автор статті «Позашкільна діяльність школярів Великої Британії з вивчення та збереження довкілля〉 Г. Марченко наголошує на тому, що залучення дітей до позашкільної екологічної діяльності позитивно впливає на їхнє виховання. Позашкільна природоохоронна робота британських навчальних закладів тісно пов'язані із краєзнавством, суспільно корисною працею, грунтується на реалізації принципу зв'язку навчання з життям. Г. Марченко зазначає, що позашкільні заходи із збереження і вивчення довкілля організовуються не тільки вчителями середніх шкіл, а й державними освітніми й екологічними установами, різними громадськими об'єднаннями, що співпрацюють із великими промисловими кампаніями. У всіх графствах країни дітей залучають до вивчення і захисту природи у поза навчальний час. Так, щороку Рада вивчення довкілля (РВД), що працює у 11 регіональних центрах, приймає 35 тис. дітей [8, с. 15]. Фахівцями установи розроблено навчальні програми, робочі та інформаційні зошити для здійснення школярами наукових досліджень із вивчення грунтів, водойм, екосистем, сільського господарства тощо. Навчальні програми РВД зосереджено на історії розвитку природозбереження, вивченні флори і фауни, геології, ландшафтів, організації походів 
сільською місцевістю тощо. Тематика дослідів укладається за принципом краєзнавчого підходу. Наприклад, учням графства Шропшир пропонується виконати наукові проекти 3 дослідження якості води в річках, що протікають територією; школярі іншого району працюють над проектом «Острів Скомер» (автор Д. Арчер-Томсон) і вивчають мешканців острова і Пемброкширського узбережжя. Завдяки залучення учнів до наукової роботи у них формується працездатність, допитливість, акуратність, почуття відповідальності, самостійність мислення, наукові здібності, вони вміють опрацьовувати різні літературні джерела, роботи узагальнення, моделювати процес розвитку відповідних регіонів тощо. Отже, залучення дітей до позашкільної природоохоронної діяльності має великий виховний вплив, грунтується на засадах співпраці і взаємодопомоги з дорослими.

Отже, проаналізовано матеріали фахового періодичного видання «Гуманізація навчально-виховного процесу» 31996 р. по 2000 р., у яких висвітлено питання трудового й екологічного виховання учнів навчальних закладів.

\section{Література}

1. Глущенко А. Г. Необхідність як умова ефективності трудового виховання / А. Г. Глущенко // Гуманізація навчально-виховного процесу : [зб. наук. праць упорядн.: Внукова I. П., Сипченко В. І.]. - Слов'янськ : СДПІ, 1996. - С. 16-18. 2. Домнич В. Г. Трудове виховання на народних традиціях - шлях до гуманізації освіти (на матеріалах іспанської народної педагогіки) / В. Г. Домнич // Гуманізація навчально-виховного процесу у вищій школі : [наукові праці міжнар. наук.-практ.конф. (27-29 вересня 1999 року)]. - Слов'янськ : Слов'янський державний педінститут, 1999. - С. 3-16. 3. Євтух М. Б. Педагогічна діяльність та педагогічні погляди М. В. Гоголя / М. Б. Євтух, К. К. Потапенко // Гуманізація навчально-виховного процесу : [наук.-метод зб. / за заг. ред. Легенького Г. І. та Сипченка В.І.]. - Вип. V. - Слов'янськ : ІЗМН-СДПІ, 1999. - С. 3-16. 4. Завгородня Т. К. Педагогічна журналістика західноукраїнських земель і проблеми шкільної дидактики (1918-1939 рр.) / Тетяна Костянтинівна Завгородня // Українська періодика : історія і сучасність : [доп. і повід. другої Всеукр. наук.-теорет. конф. 21-22 грудня 1994 р.; ред. кол.: М. М. Романюк та ін.]. - Львів; Житомир, 1994. - С. 88-90. 5. Ковальова О. В. Досвід соціального виховання в педагогічний спадщині С. Т. Шацького // Гуманізація навчально-виховного процесу : [наук.-метод зб. / за заг. ред. Легенького Г. І. та Сипченка В. І.]. - Вип. VIII. - Слов'янськ : IЗМНСДПІ, 2000. - С. 222 - 226. 6. Коновець О. Ф. Науково-просвітницька преса України XIX - перша третина XX ст. Історія. Теорія. Практика : автореф. дис. на здобуття наук. ступеня д-ра іст. наук: спец. 07.00.10 - «Історія науки і техніки» / Олександр Федорович Коновець; Київ. ун-т ім. Тараса Шевченка. - К., 1994. - 39 с. 7. Кухта М. І. Виховний національний ідеал у шкільництві Закарпаття 20-30-х років XX ст. (на матеріалах української педагогічної преси) : автореф. дис. на здобуття наук. ступеня канд. пед. наук: 13.00.01 - загальна педагогіка та історія педагогіки / Марія Іванівна Кухта. - К., 1998. - 20 с. 8. Марченко Г. В. Позашкільна діяльність школярів Великої Британії 3 вивчення та збереження довкілля / Г. В. Марченко // Гуманізація навчально-виховного процесу : [наук.-метод зб. / за заг. ред. Льогенького Г. І. та Сипченка В. І.]. - Вип. Х. - Слов’янськ : Видав. центр СДПУ, 2000. - С. 15 - 18. 9. Омельченко С. О. До питання трудового виховання учнів в умовах переходу до ринкової економіки / С. О. Омельченко // Гуманізація навчально-виховного процесу : [наук.-метод зб.]. - Вип. ІІ. - Слов'янськ : СДПІ, 1997. - С. 31-33. 10. Сипченко В. І. Виховання морально-ціннісного ставлення до праці в умовах ринкових відносин / В. І. Сипченко, С. О. Омельченко // Гуманізація навчально-виховного процесу : зб. наук. праць [упорядн.: Внукова І. П., Сипченко В. І.]. - Слов'янськ : СДПІ, 1996. - С. 18-21. 11. Чупилко Г. Р. Принцип гуманізації у трудовому вихованні підростаючого покоління / Г. Р. Чупилко // Гуманізація навчальновиховного процесу : [наук.-метод зб. / заг. ред. Легенького Г. І. та Сипченка В. I.]. - Вип. VI. Слов'янськ : ІЗМН-СДПІ, 1999. - С. 212-216. 12. Щука Г. П. Проблеми розвитку сільської школи в українській педагогічній пресі в 50-80-ті роки XX століття : автореф. дис. на здобуття наук. ступеня канд. пед. наук: 13.00.01 - «Загальна педагогіка та історія педагогіки» / Галина Петрівна Щука; Луганський нац. пед. ун-т імені Тараса Шевченка. - Луганськ, 2007. - 20 с. 